\title{
RECENZJA KSIĄŻKI DAVIDA BINGHAMA, ALBERT LIPCZINSKI. MALARZ NIEPOKORNY, WYDAWNICTWO SŁOWO/OBRAZ TERYTORIA, GDAŃSK 2011 (248 STRON)
}

Książka Albert Lipczinski. Malarz niepokorny autorstwa Davida Binghama jest efektem czteroletniego programu badawczego zainspirowanego fragmentami historii tego niedocenionego artysty. Bingham, będący wykładowcą University of Liverpool specjalizującym się w kontynentalnej filozofii europejskiej, natrafił na obraz Lipczinskiego przedstawiający profesorów tego uniwersytetu. Zaintrygowany, a wręcz zafascynowany, postanowił odtworzyć historię autora urodzonego w Polsce, który najlepsze lata życia spędził na Wyspach, by przez wojenną zawieruchę zostać zmuszonym do powrotu do ojczyzny, w której do końca życia traktowany był jak intruz.

Odtworzenie historii życia tej tragicznej postaci, mimo ogromnej ilości poświęconego czasu, nie było łatwe i nie przyniosło spektakularnych rezultatów. Autor wspomina o tym na początku i w zasadzie nie daje czytelnikowi o tym fakcie zapomnieć przez cały czas - książka wydaje się mieć charakter patchworku czy niekompletnej układanki, w której opisy o zaskakującej szczegółowości przeplatają się z przypuszczeniami i domniemaniami. Taka struktura spowodowana jest faktem, że malarz nie pozostawił po sobie żadnych zapisków ani dokumentów, a jego postać nie była na tyle istotna w artystyczno-naukowym życiu Liverpoolu początku XX w., by pozostawić po sobie wyraźny ślad w świadectwach z tego okresu.

Tak naprawdę tytuł książki może być mylący, gdyż w gruncie rzeczy Lipczinski nie jest głównym bohaterem opowieści, a raczej postacią łączącą różne światy, czasy i porządki w jedną, poruszającą, trwającą blisko sto lat historię.

* Mgr, doktorantka, Katedra Socjologii Sztuki, Instytut Socjologii, Wydział Ekonomiczno-Socjologiczny, Uniwersytet Łódzki, ul. Rewolucji 1905 r. 41/43, 90-214 Łódź; e-mail: ola.wysokinska@gmail.com. 
Znajdziemy w niej fascynujące opisy tworzenia się i rozkwitu liverpoolskiej bohemy artystycznej, która grupowała się w stowarzyszenia, zakładała własne uczelnie i organizowała głośne wystawy, dając światu niezwykle płodnych i nowatorskich artystów. Obserwujemy wybuchy rewolucji w tym robotniczym mieście, wspierane przez zaangażowanych twórców i krwawo tłumione przez władze. Czytamy o okrucieństwach wojny i niedoli, w jaką wpędzała niewinnych ludzi, czyniąc spustoszenie w całej Europie, pozbawiając ludzi dobytku i godności. Odnajdziemy również poruszającą historię miłości na całe życie, trudnej, burzliwej i przynoszącej cierpienia, ale jednak będącej jedyną opoką w trudnych czasach. Poznamy, co to prawdziwa przyjaźń, łącząca ludzi na całe dekady, niezważająca na pochodzenie i status, dająca mnóstwo radosnych i ciepłych chwil. Zatem o czym traktuje ta pozycja? Wyróżniłabym tu dwa główne wątki. Pierwszy - radosny - wprowadza czytelnika w niuanse życia angielskich elit intelektualnych pierwszych dwóch dekad XX w. Drugi to historia odrzucenia i upadku człowieka, a w zasadzie dwójki ludzi, który pozostawia odbiorcę w nastroju przygnębienia i poczucia potwornej niesprawiedliwości.

Licząca ponad 200 stron, pięknie wydana książka, podzielona jest na 18 kilku- lub kilkunastostronicowych rozdziałów, poprzedzonych mottem, uporządkowanych chronologicznie, skupiających się na wybranych aspektach opisywanego świata, do którego należał Lipczinski z żoną, ale - jak już wspomniałam - był w nim postacią co najwyżej drugoplanową, a czasem tylko przewijał się w tle opisywanych wydarzeń. Znajdujemy więc części traktujące o Sandonistach, walijskich Cyganach czy postimpresjonistach. Wskazówką, kto interesował Bighama najbardziej, jest - oprócz tytułu - notka długości jednej strony, otwierająca książkę. Podrozdział zatytułowany Artysta w bardzo skondensowany sposób opisuje dokonania malarza, skupiając się na jego największych dziełach i wystawach, które uświetniał swoimi pracami. Można odnieść wrażenie, że autor próbuje na wstępie udowodnić, że jest to postać zasługująca na nieco uwagi. Powyżej opisana konstrukcja publikacji sprawia, że czyta się ją lekko, z ciekawością pochłaniając kolejne anegdoty i opowieści. Lekturę urozmaica obszerny zbiór ilustracji doskonałej jakości, przedstawiających przede wszystkim reprodukcje obrazów i rysunków, niekoniecznie autorstwa Lipczinskiego. Niestety, ten radosny i twórczy nastrój właściwy okresowi młodości ulega zupełnemu odwróceniu w kolejnych latach, prezentowanych w dalszej części książki, co sprawia, iż pozostawia ona odbiorcę w zadumie nad nieprzewidywalnością ludzkiego losu.

Bardzo przygnębiającym elementem biografii jest nieustanne poczucie wyobcowania artysty, który nigdy nie jest tak naprawdę u siebie. Doznanie to jest niewątpliwie pogłębiane przez silne poczucie indywidualności malarza i jego trudny charakter. W dramatycznych okolicznościach, jako młody chłopak, zmuszony był uciekać z rodzinnych Prus. Trafił (zapewne przypadkiem i mimo woli) do Anglii, nie znając języka, nie mając perspektyw, ale osiedlił się tam na stałe dopiero kilka lat później, po europejskiej tułaczce (jak przypuszcza autor). Dzięki 
żonie, Angielce o wielu znajomościach w świecie artystycznym, zasymilował się i zintegrował z liverpoolskim środowiskiem. I kiedy już wydawało się, że odnalazł swoje miejsce na świecie, jego przybrana ojczyzna wyrzekła się go - najpierw został uwięziony, a później wypędzony tam, skąd przybył. Wolne Miasto Gdańsk wydawało się po zakończeniu II wojny światowej dobrą przystanią, jednak okazało się, że tereny te stały się areną walk polityczno-obyczajowych, co przysporzyło artyście trudności i nie pozwoliło w pełni się zadomowić, nie wspominając już o jego towarzyszce życia. Sprawy przybrały jeszcze bardziej dramatyczny obrót podczas wojny oraz po niej, kiedy wprowadzony został ustrój socjalistyczny. Wcześniej bezpieczny jako Niemiec, w późniejszym czasie musiał prezentować polską część swojej tożsamości, by uniknąć wysiedlenia. Jednak niedola, jaka stała się jego udziałem w latach 40., towarzyszyła mu do końca życia. Bieda, głód i gnębienie przez system odbijały się na relacjach z żoną, zdrowiu (zarówno fizycznym, jak i psychicznym), a w końcu - na twórczości. Lipczinski umarł więc w nędzy, samotności i zapomnieniu, w miejscu obcym (chociaż zamieszkiwanym przez wiele lat) i nieprzyjaznym. 